\title{
Analysis of nuclear degradation during lens cell differentiation
}

\author{
Marie France Counis ${ }^{1}$, Elisabeth Chaudun ${ }^{1}$, Cristina Arruti ${ }^{2}$, \\ Lisa Oliver ${ }^{3}$, Madhu Sanwal ${ }^{4}$, Yves Courtois ${ }^{1}$ and \\ Alicia Torriglia ${ }^{1}$ \\ 1 U450 INSERM, développement, vieillissement et pathologie de la rétine, Unité \\ associée CNRS, Association Claude Bernard, 29 rue Wilhem, 75016 Paris, \\ France \\ ${ }^{2}$ Laboratorio de Cultivo de Tejidos, Facultad de Medicina, Av General Flores \\ 2125, 11800, Montevideo, Uruguay \\ 3 INSERM U 419, Institut de Biologie, 9 quai Moncousu, 44035 Nantes Cédex \\ 01, France \\ ${ }^{4}$ University of Western Ontario, Department of Biochemistry, London, NGA 5C1 \\ Canada \\ ${ }^{5}$ corresponding author: MF Counis. tel: 3301452521 93; fax: 3301405001 \\ 95
}

Received 16.6.97; revised: 23.9.97; accepted 19.11.97

Edited by R.A. Knight

\begin{abstract}
Lens cells demonstrate a terminal differentiation process with loss of their organelles including nuclei. Chromatin disappearance is characterised by the same changes as most apoptotic cells, i.e. condensation of chromatin and cleavage into high molecular weight fragments and oligonucleosomes. The endo-deoxyribonucleases (bicationic $\left(\mathrm{Ca}^{2+}, \mathrm{Mg}^{2+}\right)$, mono-cationic $\left(\mathrm{Ca}^{2+}\right.$ or $\left.\mathrm{Mg}^{2+}\right)$ and acidic non-cationic dependent nucleases) are present in lens fibre cells. Our results suggest that the acidic non-cationic nuclease (DNase II) plays a major role in chromatin cleavage. This nuclease, known to be lysosomal, is found in lens fibre nuclei and only an antibody directed against DNase II inhibits the acidic DNA cleavage of lens fibre nuclei. In addition, there must be another DNase implicated in the process which is not DNase I but appears to be a $\mathrm{Ca}^{2+}, \mathrm{Mg}^{2+}$ dependent molecule. Regulation of these DNase activities may be accomplished by the effect of post-translational modifications, acidic $\mathrm{pH}$, mitochondrial release molecules, growth factors or oncogenes. Finally, fibre cells lose organelles without cytoplasmic elimination. The survival of these differentiated cells might be due to the action of survival factors such as FGF 1.
\end{abstract}

Keywords: lens cells; differentiation; nuclear apoptosis; genome cleavage; DNases

Abbreviations: AIF, apoptosis inducing factor; AP, annular pad; DAPI, 4',6-diamidino-2-phenylindole; DNase, deoxyribonuclease; DSB, double strand breaks; E15, embryonic day 15; EDTA, ethylene diamino tetra acetic; Ep, epithelia; FGF, fibroblast growth factor; HMG, High mobility group proteins; $\mathrm{HMW}$, high molecularweight; HPV, human papiloma virus; ICE, interleukin- $1 \beta$ converting enzyme; IF, inner fibre cells; NT, nick translation; OF; outer fibre cells; PMSF, phenyl methyl sulfonyl fluoride; $\mathrm{Rb}$, retinoblastoma; RPN, ribonuclear proteins; SDS, sodium dodecyl sulphate; SSB, single strand breaks; SV, simian virus; TNF, tumour necrosis factor; TUNEL, TdTmediated dUTP-biotin nick end labelling; UV, ultraviolet

\section{Introduction}

The eye lens is a useful model for the examination of many fundamental processes occurring during embryonic development (reviewed by Cvekl and Piatigorsky, 1996; Wride, 1996; Zelenka et al, 1996; Lang, 1997). Cellular differentiation of the lens is accompanied by nuclear degeneration similar to that appearing during apoptosis.

This avascular organ (Figure 1), surrounded by a capsule, is composed of a layer of epithelial cells and internally, a mass of elongated cells, the fibres. In the equatorial region of the lens, the epithelial cells elongate into fibres, DNA synthesis is arrested and high concentrations of crystalline proteins accumulate (Piatigorsky, 1981). The loss of organelles is extensive in these terminally differentiating lens fibres. It affects the mitochondria (Bassnett and Beebe, 1992), the endoplasmic reticulum (Bassnett, 1995) and some components of the cytoskeleton such as intermediate filaments and microtubules (Kuwabara and Imaizumi 1974; Bradley et al, 1979; Vrensen et al, 1991; Sandilands et al, 1995). One of the most striking features is nuclear degeneration, first described by Modak (Modak et al, 1969; Modak and Perdue, 1970) that mimics nuclear oligonucleosomal degradation (Appleby and Modak, 1977), often described in apoptosis (Wyllie, 1980; Wyllie et al, 1980). Despite these changes, the anucleate fibre cells remain within the lens throughout the life span of the individual.

Unlike apoptotic cells which die randomly, the fibre cells differentiate, following a highly ordered pattern of temporal progression. This allows the study of nuclear fate and DNase activation (Counis et al, 1989a). Microdissection of an embryonic or post-hatch chicken lens separates the nucleated, undifferentiated epithelial cells attached to the capsule from the underlying postmitotic, differentiated fibre cells. Thus, cells from the same lineage, yet differing in metabolism and differentiation state can be compared.

\section{Modification of lens nuclei during terminal differentiation}

Lens fibre differentiation from epithelia to fibre cells exhibits a remarkable change in nuclear shape and morphology (Figure $2 A-D)$. Epithelial nuclei (Figure $2 A$ ) and outer fibre nuclei are slightly round, then, as they mature, the nuclei elongate 
(Figure 2B and $\mathrm{C}$ ) and shrink to a globular and highly condensed shape (Figure 2D) (Sanwal et al, 1986). In 1970, Modak and Perdue demonstrated by Feulgen and UV

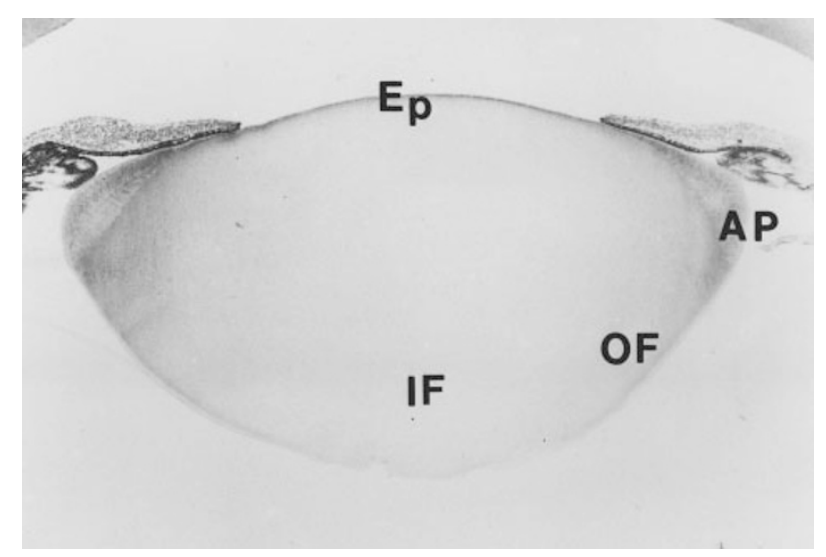

Figure 1 Embryonic chick lens central section at E18 stained with 1\% toluidine blue $(\times 25)$ showing Ep: epithelia. AP: annular pad, OF: outer fiber cells with elongated nuclei. IF: inner fiber cells with round nuclei
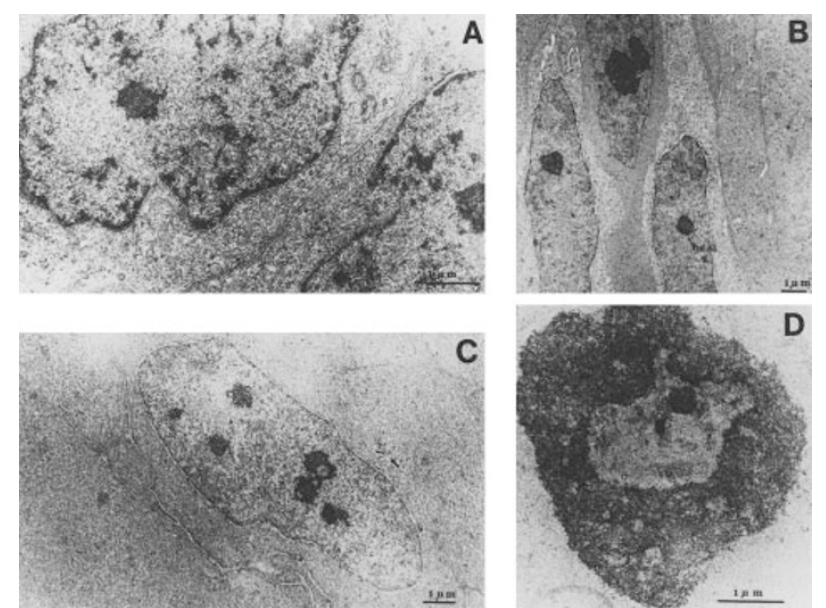

Figure 2 (A, B, C and D) transmission electron microscopy of nuclei from embryonic chick lens cells. Equatorial epithelial nuclei at E11 (A). Outer fibre nuclei at E11 (B) and E18 (C). Central fibre nuclei at E18 (D) (Sanwal et al, 1986) microspectrophotometric analysis the loss of DNA from the central and pycnotic fibre cell population. The nuclei from these cells contain amounts of DNA equivalent to the $1 \mathrm{C}$ value, while that of epithelial and annular pad cell populations range between $2-4 \mathrm{c}$. We have confirmed this result (Yamamoto et al, 1990) using microfluorometry with Hoechst 33258 fluorochrome, in the presence of $\mathrm{NaCl}$ to increase accessibility of DNA to dye. We have shown a decrease in the amount of DNA in lens fibre nuclei during embryonic and postnatal development not observed in epithelial cell nuclei. In the nuclei of mouse central lens fibres, Vrensen et al (1991) describe an accumulation of osmiophilic or dense bodies in the nucleoplasm. These appear to be extruded into the cytoplasm and then the extracellular space. This material could represent fragments of chromatin or RNP particles as Sanwal et al (1986) observed earlier.

Cleavage of the chromatin may be modulated by the structure of DNA itself, affected by the nuclear protein environment. Among the different proteins implicated in chromatin stability, histone $\mathrm{H} 1$ plays a fundamental role at the linker of the nucleosome and in compacting polynucleosome chains into higher-order structures. HMG-14 nuclear protein has different DNA binding domains and shows affinity for DNA within the nucleosomal core (Trieschmann et al, 1995; Lovell-Badge, 1995). Thus with specific antibodies raised against histone $\mathrm{H} 1$ and HMG-14, we studied the loss of both nuclear proteins during lens cell development and differentiation with the idea that the linker protein would be lost first and this, would increase DNase efficacy. Curiously, HMB-14 is lost quite early during embryonic development (Table 1; Figures 3 and 4). HMG-14 is observed in all lens nuclei at 11 day of embryonic development, E11 (Figure 3), yet is completely absent in central round nuclei at E18 and at older stages (Figure 4). Histone $\mathrm{H} 1$ is conserved, and can still be observed at 11 day post-hatching but is completely absent 7 days later (Table 1). Histone $\mathrm{H} 1$ belongs, in fact, to a family of proteins that can be resolved into different subfractions. The histone variant $\mathrm{H} 1-2$ (Table 1) is not observed in embryonic fibres though it is seen in epithelial cells at the same age (Roche et al, 1992). These results may indicate that DNA is depleted of protective proteins during lens fibre differentiation, a feature which may favour the actions of endonucleases.

Table 1 Nuclear proteins of lens fibre chromatin

\begin{tabular}{|c|c|c|c|c|c|c|}
\hline \multirow{3}{*}{$\begin{array}{l}\text { Stages } \\
\text { in days }\end{array}$} & \multicolumn{2}{|c|}{ HMG 14 (1) } & \multicolumn{2}{|c|}{ Histone H1 (1) } & & \\
\hline & OE & CR & OE & CR & \multicolumn{2}{|c|}{ Histone (2) } \\
\hline & \multicolumn{2}{|c|}{ nuclei } & \multicolumn{2}{|c|}{ nuclei } & H1-1 & H1-2 \\
\hline E 6 & ++ & no CR & nd & nd & nd & nd \\
\hline E 11 & ++ & ++ & ++ & + & + & - \\
\hline E 14 & nd & nd & nd & nd & + & - \\
\hline E 18 & ++ & - & ++ & + & + & - \\
\hline $\mathrm{PH} 4$ & ++ & - & nd & nd & nd & nd \\
\hline $\mathrm{PH} 11$ & ++ & - & ++ & + & nd & nd \\
\hline $\mathrm{PH} 18$ & ++ & - & ++ & - & nd & nd \\
\hline PH 32 & ++ & - & nd & nd & nd & nd \\
\hline
\end{tabular}

OE: outer elongated nuclei; CR: central round nuclei; E: embryonic stage; PH: post hatch stage. (1) Results obtained by immunofluorescence with polyclonal antibodies directed against HMG 14 and Histone H 1. (2) PAGE analysis revealed by Coomassie, autoradiography and Western blot (Roche et al., 1992). nd: not determined 

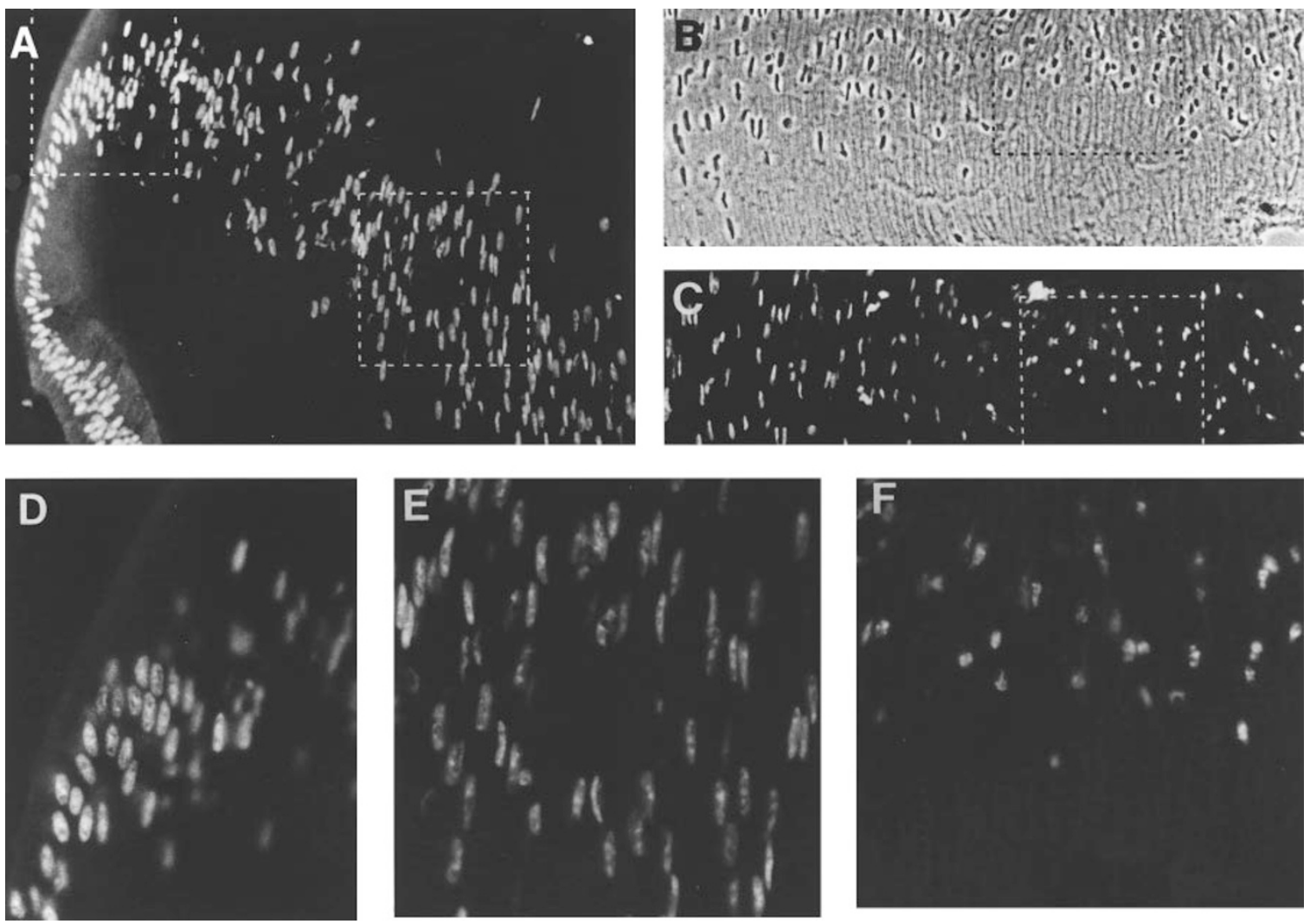

Figure 3 Indirect immunofluorescence of E11 lens sections incubated with a polyclonal antibody against HMG14. (A) annular pad and outer fibres ( $\times 16)$. (B) and (C) central fibres with elongated and round nuclei $(\times 16)$. B corresponding phase contrast to $\mathbf{C}$. (D, E, F) higher magnification $(\times 40)$ of insets from $\mathbf{A}(\mathbf{D}$ and $\mathbf{E})$ and B, C (F): (D) annular pad, (E) outer fibres and $(\mathbf{F})$ central fibres
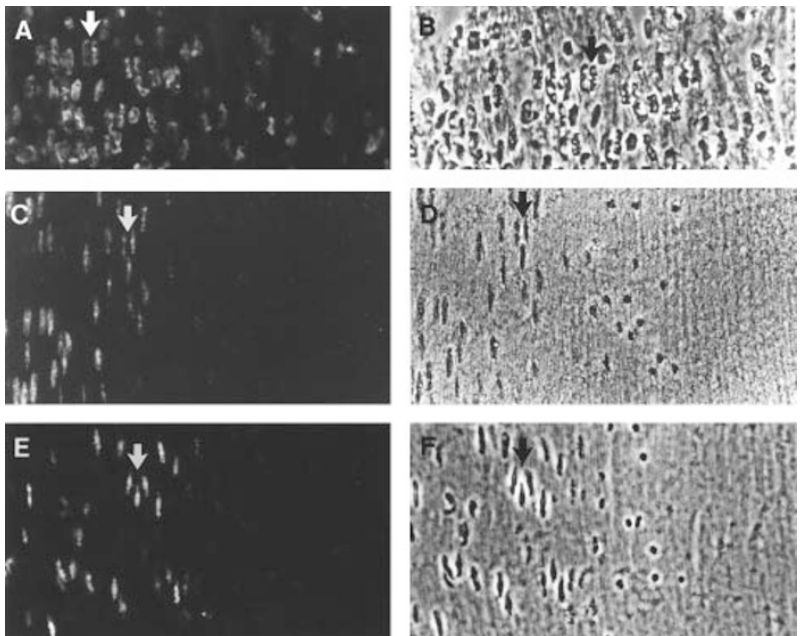

Figure 4 E6 (A, B), E18 (C, D) and 4 day post hatch lens (E, F) sections incubated with a polyclonal antibody against HMG14 showing central elongated and round fibre nuclei $(\times 40)$. Indirect immunofluorescence $(A, C$, E) and corresponding phase contrast (B, D, F). Arrows show the same group of cells in each pair of pictures

Nevertheless, the data are not sufficiently definitive to state whether the protein depletion precedes or parallels DNA degradation.

\section{DNA cleavage}

Non-random DNA degradation occurs in terminally differentiating lens cells; fragment size has been determined by sucrose gradient analysis or agarose gel electrophoresis. DNA ladders derive from large fragments of DNA, coming themselves from high molecular weight DNA. In a healthy lens epithelial cell, the DNA has a high molecular weight of $>165$ $S$ and sediments to the bottom of an alkaline sucrose gradient as a homogenous population (Counis et al, 1977). As differentiation progresses, it appears in the middle region of the same gradient, a polydisperse DNA population with an average molecular weight of $64 \mathrm{~S}$. This last population is also observed when lens cells are X-irradiated, and corresponds to the high molecular weight DNA populations observed during apoptosis resolved by pulse field gel analysis (Cain et al, 1994). The same specific sites of DNA cleavage were detected as in apoptotic cells.

From an historical point of view, DNA degradation in fibre cells was first studied in vitro using isolated nuclei. In 1977, Appleby and Modak showed that the cells located in the central regions of the lens contained DNA with an oligonucleosome banding pattern when analyzed in neutral agarose gels. This is detected at E15 and later stages. We have recorded a similar pattern (Muel et al, 1986) in isolated fibre cell nuclei, present here at E11 and E18 (Figure 5). DNA cleavage of these nuclei, incubated for 
different times in $10 \mathrm{mM}$ Tris $\mathrm{HCl}, \mathrm{pH} 7.4$ containing $0.34 \mathrm{M}$ sucrose, $15 \mathrm{mM}$ 2-mercaptoethanol and $0.05 \mathrm{mM} P M S F$, is also visualized in neutral agarose gels. An oligonucleosomal ladder is only recorded with lens fibre chromatin; this DNA cleavage is first visible at E11 and at subsequent stages.

As early as the late 1970s, it was apparent to us that the pattern of DNA cleavage was progressive, with a multi-step mechanism, from monodisperse, high molecular weight DNA to a polydisperse DNA population (Counis et al, 1977). Only a fraction of the total DNA was cleaved into oligonucleosomal fragments that characterise the DNA ladder. The accumulation of DNA strand breaks could be the result of either an increase in DNase activity or of an impairment in DNA repair. It is probable that both processes play an active part in the genome loss. To this end, we have shown a gradual decrease of the DNA synthesising enzymes. At E10, the DNA polymerase $\alpha$ activity is lower in chick lens fibres than in epithelial cells. In 14.5 month old chick fibres, there is a total disappearance of DNA polymerases ( $\alpha$ and $\beta$ ) and DNA ligases (Counis et al, 1981). This loss of polymerases may be more likely related to decreased cell cycle traverse. The typical DNA cleavage frequently observed in many examples of programmed cell death has led to the hypothesis that there is also present an active endodeoxyribonuclease capable of producing double stranded breaks (DSB) in the DNA of differentiating lens fibre nuclei.

\section{Endodeoxyribonuclease activity in lens fibre cells}

There are several arguments that suggest the existence of an endonuclease activity in lens fibre cells. Oligonucleosomes are only observed in fibre nuclei (Figure $5 \mathrm{~A}$ and $\mathrm{B}$ ) incubated in neutral buffer with no exogenously added cations. In the same conditions, no nucleosomal ladder is observed in epithelial cells. This results in DSB suggesting the presence
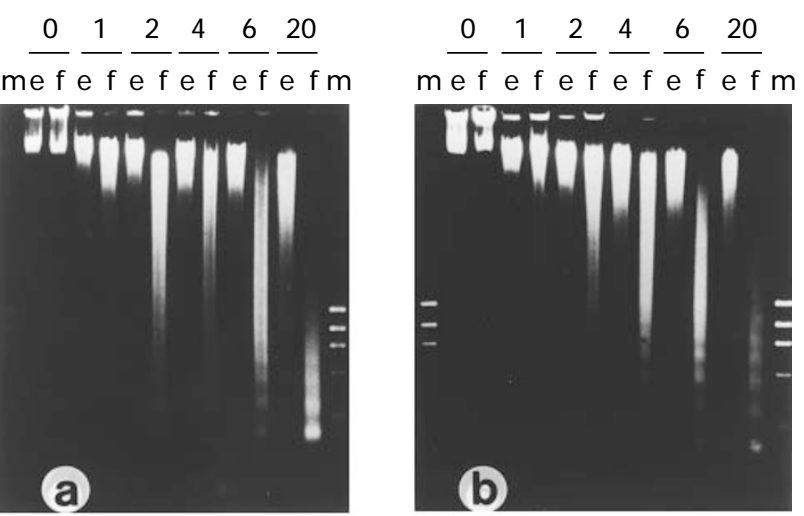

Figure 5 Electrophoretic analysis on 1\% neutral agarose gel of oligonucleosomes produced by autodigestion of lens fibre nuclei (f) at E11 (a) and E18 (b). Compare the $f$ lanes with e lanes corresponding to epithelial cell nuclei (Muel et al, 1986). Nuclei were incubated during $0,1,2,4,6$ and $20 \mathrm{~h}$ in $10 \mathrm{mM}$ Tris$\mathrm{HCl}(\mathrm{pH} 7.4), 0.34 \mathrm{M}$ sucrose, $0.05 \mathrm{mM}$ PMSF and $15 \mathrm{mM}$ 2-mercaptoethanol. Markers $(\mathrm{m}): \mathrm{f} \times 174$ RF-DNA Haell digests $(1352,1078,872,603,311,271$, 234, $194 \mathrm{bp})$ of a nuclease (Appleby and Modak, 1977; Muel et al, 1986). However, it has also been demonstrated that oligonucleosomal ladder formation is strictly dependent on the presence of cations. Increasing amounts of EDTA or EGTA prevent nucleosomal formation. This nuclease activity cleaves completely, after a lag of $4 \mathrm{~h}$, several genes such as $\alpha$ crystallin, $\beta$ tubulin and vimentin (detectable in nuclei, at E11, by Southern blot (Muel et al, 1989)). A nuclear or cytoplasmic extract from lens fibres contains a nuclease, the activity of which is capable of cleaving a supercoiled PM2 DNA (Counis et al, 1986). This endonuclease activity increases in the nuclear fraction from E15 to E18, leading to a decrease of the cytoplasm/nuclear ratio from 100 to 16 .

However, in epithelial cells with an intact nucleus, there is also an endonuclease activity capable of cleaving a supercoiled PM2 DNA. This activity is present in the cytoplasm at E15 and E18 but is always higher in fibres (Counis et al, 1986). In epithelial nuclei incubated as above, no oligonucleosome formation can be seen, just a smear of high molecular weight DNA appears after incubation (Muel et al, 1986). Evidence of nucleosome distribution, however, has been seen in epithelial nuclei. If epithelial lens cells are irradiated with X-rays, and the nuclei prepared as above, it is then possible to observe faint oligonucleosome formation after a delay of $20 \mathrm{~h}$ (Trevithick et al, 1987).

In conclusion, differentiating fibre cells contain endodeoxyribonuclease(s) capable of cleaving supercoiled DNA substrate and fibre chromatin into nucleosomal ladders. Epithelial cell nuclei also contain endonuclease activity which can be activated. However, we do not yet know if both compartments share the same nuclease molecules.

\section{Classification of lens DNases}

DNase activities may be classified into three main groups. The first group is the class of DNase I-like molecules, with an absolute $\mathrm{Ca}^{2+}, \mathrm{Mg}^{2+}$-dependence. The second group includes the acidic or DNase II-like nucleases, with no cation dependence. The third group contains DNases with dependence on only one cation, such as $\mathrm{Mg}^{2+}, \mathrm{Mn}^{2+}$ or $\mathrm{Ca}^{2+}$.

\section{The $\mathrm{Ca}^{2+}, \mathrm{Mg}^{2+}$-dependent DNases}

The first group, of which the best known enzyme is DNase I, comprises all $\mathrm{Ca}^{2+}, \mathrm{Mg}^{2+}$-dependent enzymes. DNase I has been reviewed by Moore (1981). First purified from bovine pancreas, this $30 \mathrm{kDa}$ polypeptide has a $\mathrm{Ca}^{2+}, \mathrm{Mg}^{2+}$ dependence with an optimal activity at neutral $\mathrm{pH}$. It has a natural and specific inhibitor, G-actin, and is also inhibited by zinc and aurintricarboxylic acid (ATA). DNase I cleaves DNA by producing single (SSB) and double (DSB) strand breaks with free $3^{\prime} \mathrm{OH}$ ends (Mannherz, 1992). It has been cloned and sequenced from different species: rat (Polzar and Mannherz, 1991), bovine Worrall and Connolly, 1990) and human (Shak et al, 1990). It is the best characterised eukaryotic nuclease.

Hewish and Burgoyne (1973) first demonstrated that chromatin from liver nuclei could be autodigested, in the presence of divalent cations $\left(\mathrm{Ca}^{2+}, \mathrm{Mg}^{2+}\right)$, into regular sub- 
structures which appear to be multiples of the smallest size unit. Since then, Wyllie (1980) and others, including ourselves have studied $\mathrm{Ca}^{2+}, \mathrm{Mg}^{2+}$-dependent DNase, suggesting that it plays a role in oligonucleosomal ladder formation. Wyllie and coworkers isolated this activity from thymocytes as a protein of $110-130 \mathrm{kDa}$, which they reported to be closely related to one subunit of topoisomerase II (Arends et al, 1990; Arends and Wyllie, 1991). Lack (1981) identified in nuclease activity gels or zymograms, a $30 \mathrm{kDa}$ protein, whose activity was $\mathrm{Ca}^{2+}, \mathrm{Mg}^{2+}$-dependent, in tissues such as parotid and submaxillary salivary glands and small intestine, lymph node, kidney, heart, prostate gland and seminal vesicles. Ucker et al (1992) using the same technique, showed a doublet at $40 \mathrm{kDa}$, with nuclease dependent $\mathrm{Ca}^{2+}$ and $\mathrm{Mg}^{2+}$ activity, in NIH3T3 fibroblast nuclei and in (SV40)-transformed fibroblast nuclei. Gaido and Cidlowski (1991) have isolated an $18 \mathrm{kDa}$ nuclease from rat thymus which can also be classified as belonging to the DNase I family. Recently, Pandey et al (1997) purified a novel $97 \mathrm{kDa}$ endonuclease.
In lens fibre cell extracts, neutral $\mathrm{Ca}^{2+}, \mathrm{Mg}^{2+}$-dependent nuclease activity was measured (Figure $6 \mathrm{~A}$ ) by a specific assay capable of discriminating the $\mathrm{Ca}^{2+}, \mathrm{Mg}^{2+}$-nucleases from acidic, non-cationic DNases (Torriglia et al, 1995). This bi-cationic activity represented in fact several DNase activities. After isoelectrofocusing electrophoresis followed by an activity transfer to an agarose gel containing DNA, two polypeptides with an acidic charge (pl 5.2 and 5.3) displayed this activity. By comparison, commercial DNase I has a pl of 5.3 (Counis et al, 1989b). Using a gel activity technique (i.e. Laemmli gels containing DNA), two $\mathrm{Ca}^{2+}$, $\mathrm{Mg}^{2+}$-dependent activities corresponding to 30 and $60 \mathrm{kDa}$ polypeptides were observed (Figure 6B) in a Tris-SDS lens fibre extract (Arruti et al, 1995). These cationic activities, noted in both chicken embryonic lens fibre cells and completely anucleate fibre cells (hen of 1.5 years old), are dependent strictly on $\mathrm{Ca}^{2+}$ and $\mathrm{Mg}^{2+}$ and inhibited by $\mathrm{a}$ specific inhibitor of DNase I, G-actin (Arruti et al, 1995). It has been hypothesised that these cationic DNase activities accumulating in lens fibre cells at an older stage could

A

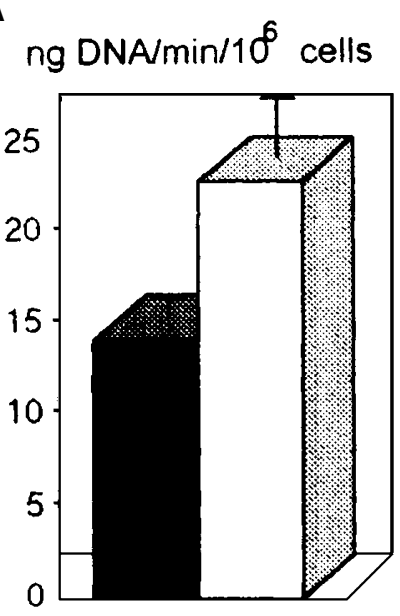

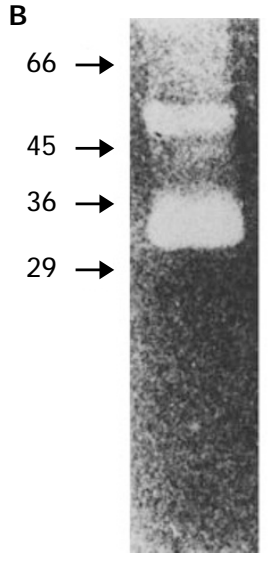

1

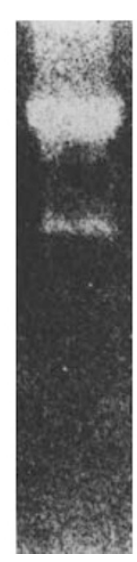

2
C

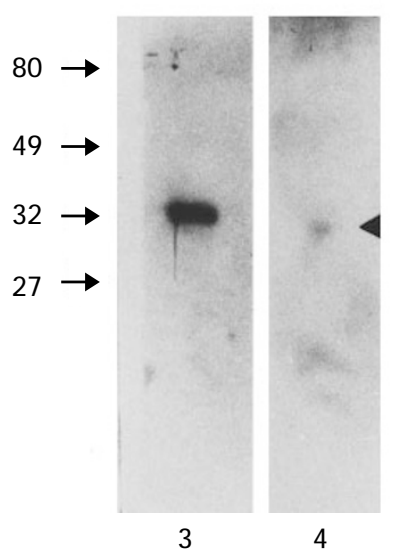

D

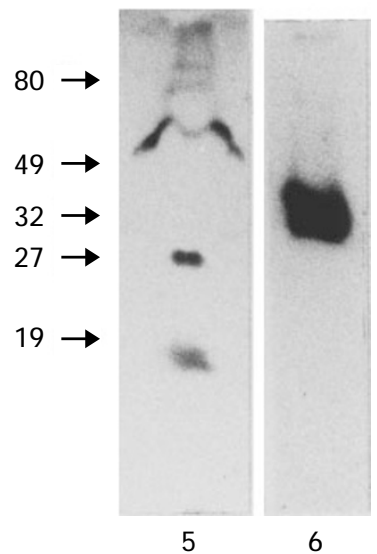

Figure 6 DNase content in chick lens fibre cells. (A): DNase activity assay, depicting the presence of neutral $\mathrm{Ca}^{2+}, \mathrm{Mg}^{2+}($ dark bar) and acidic-noncationic (white bar) DNase activities at E18 (Torriglia et al, 1995). (B): Non radioactive activity gel showing cationic $\left(\mathrm{Ca}^{2+}, \mathrm{Mg}^{2+}\right) \mathrm{DNase}^{2}$ activities in outer (1) and central (2) 2 month old lens fibre extracts (Arruti et al, 1995). E18 lens fibre DNase I (C) and DNase II (D) detected by Western blot with specific anti-DNases. Control DNase I (3). DNase I (4) and DNase II (5) detected in a E18 fibre extract. Control DNase II (6) (Torriglia et al, 1995) 
have another function as nuclei have long disappeared. They may be linked to $\alpha$ crystallin, via G-actin, and play a role in ultrastructural organisation of the lens fibre itself (Gopalakrishnan and Takemoto, 1992).

These DNase I-like enzymes were further immuno characterised using an anti-DNase I raised against bovine pancreatic DNase I. This antibody inhibits DNase I activity in vitro (Torriglia et al, 1995). A single band of $32 \mathrm{kDa}$ was detected by Western blot (Figure 6C, lane 4). When considering the immunochemistry data, DNase I (Figure 7, panel 2) was found in the nuclei of E18 fibre cells (corresponding nuclear staining DAPI, Figure 7, panel 1).

In epithelial cells, we have observed a $\mathrm{Ca}^{2+}, \mathrm{Mg}^{2+}$. dependent nuclease activity which was reduced compared to that in fibres, when expressed per cell number. Three main polypeptides were labelled with an antibody directed against DNase I, in Western blot $(60,32$ and $18 \mathrm{kDa})$ (Torriglia et al, 1995). These DNase I-like molecules were found mainly in the nuclei (Figure 7, panel 4; corresponding nuclear staining DAPI, panel 3) of epithelial cells in lens sections, when observed by immunohistochemistry (Torriglia et al, 1995).

Different techniques suggest that several $\mathrm{Ca}^{2+}, \mathrm{Mg}^{2+}$ dependent nucleases exist in lens fibre cells, characterised either by their pl or by their molecular weight as in apoptotic cells (30 kDa DNase I, NUC 18 and the new $97 \mathrm{kDa}$ ). If we consider that the active DNase I is the $30 \mathrm{kDa}$ polypeptide, other $\mathrm{Ca}^{2+}, \mathrm{Mg}^{2+}$ nuclease activities exist, probably not related to DNase I. It is noteworthy that all these polypeptides require millimolar concentrations of $\mathrm{Ca}^{2+}$ and $\mathrm{Mg}^{2+}$ when assayed in vitro, but the intracellular $\mathrm{Ca}^{2+}$ level is in the nanomolar range. This is well below the concentration required to activate the enzymes in vitro (Barry and Eastman, 1992).

\section{Non-cationic DNases}

The second group of DNases corresponds to DNase II-like activity. DNase II has been described by Bernardi (1971) and Liao et al (1989). Initially purified from porcine spleen, it has a molecular weight of $40-46 \mathrm{kDa}$, and is composed of two subunits of 35 and $10 \mathrm{kDa}$. DNase II cleaves DNA in sodium acetate buffer $(150 \mathrm{mM})$ and in the presence of EDTA $(10 \mathrm{mM})$, with an optimal acidic $\mathrm{pH}(4.6-5)$, produces DSB and SSB with $3^{\prime}$ phosphate ends. Having been neither sequenced nor cloned; it is not as well known as DNase I and few authors have studied this molecule. Yasuda et al (1992) purified a $32 \mathrm{kDa}$ protein with DNase II activity. This activity can be detected in many human tissues including liver, kidney, spleen, lung, heart, pancreas, thymus and salivary fluid suggesting an ubiquitous nuclease.

In lens fibre cells, the assay discriminating the acidic $(\mathrm{pH}$ $5.5)$, non-cationic nuclease activity from cationic and neutral DNase has shown an acidic nuclease activity (Figure 6A) in fibre cells (Torriglia et al, 1995). We have not been able to use the denaturating gel activity technique to detect any DNase II activity in tissues or any purified commercial preparations even if the reducing agent is omitted. This differs from the findings of Mezzina (1989) in lymphocytes and Pandey et al (1997) in rat hepatoma cells. We have prepared a polyclonal antibody against DNase II (27 kDa from Worthington) having a high titre. It does not cross-react with DNase I and is able to inhibit DNase II activity in vitro (Torriglia et al, 1995). In fibre cells, DNase II
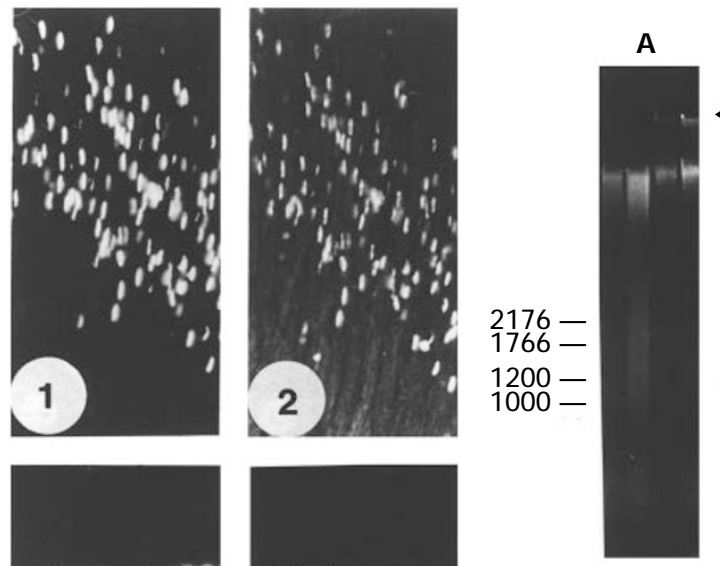

1234

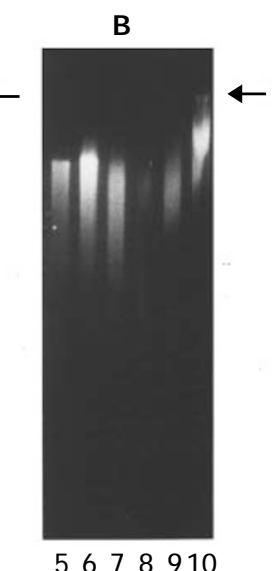

5678910
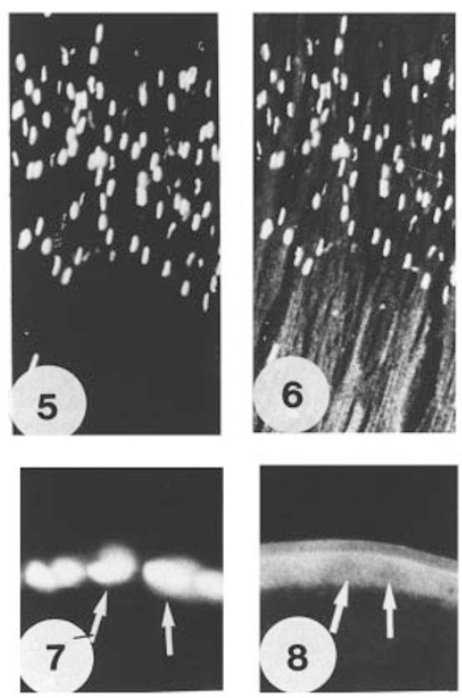

Figure 7 Localisation and function of cation dependent $\left(\mathrm{Ca}^{2+}, \mathrm{Mg}^{2+}\right)$ and acidic, non cationic DNases (Torriglia et al, 1995). Nuclear localisation of DNase I in lens outer fibre nuclei (panel 2) or in epithelial nuclei (panel 4). Nuclear Dapi stain of the same section (panels 1 and 3 ). Nuclear localisation of DNase II in lens outer fibre nuclei (panel 6) and cytoplasmic localisation in epithelial cells (panel 8). Nuclear Dapi stain of the same section (panels 5 and 7 ). Effect of the antiDNase I and anti-DNase II antibodies on DNA cleavage: $10^{6}$ lens epithelial (A) or fibre (B) nuclei were incubated $6 \mathrm{~h}$ in neutral cationic or in acidic, non-cationic medium in absence or in presence of an anti-DNase I or DNase II antibody. Arrow indicate the sample well. (A) Acidic non-cationic DNase nuclease activity in E18 epithelial cells (lane 3) is not inhibited by anti-DNase II (lane 4) nor is cationic nuclease activity in same tissue (lane 1) by anti-DNase I (lane 2). (B) Acidic non cationic DNase activity in E18 fibre nuclei (lane 8 ) is inhibited by anti-DNase II antibody (lanes $9-10$ ) while cationic nuclease activity in E18 fibre nuclei (lane 5 ) is not inhibited by anti-DNase I antibody (lanes 6-7) 
antibody recognises three major bands $(60,23$ and $18 \mathrm{kDa})$ which are detected, at least for two of them (60 and $23 \mathrm{kDa}$ ) only in these differentiating cells as compared to epithelial cells (Figure 6D, lane 5). Immunolocalization (Figure 7, panel 6; corresponding nuclear staining DAPI, panel 5) shows the presence of DNase II, highly concentrated, in all populations of fibre nuclei programmed to degenerate, although the DNase II is known to be a lysosomal enzyme (Liao et al. 1989). Other authors have also found this enzyme in nuclei (Slor and Lev, 1971).

In non-differentiating lens epithelial cells, there is also some acidic and non-cationic nuclease activity, to a lesser extent than in differentiating fibre cells. Western blotting shows two immunoreactive bands of 100 and $18 \mathrm{kDa}$ which are located in cytoplasm (Figure 7, panel 8; corresponding nuclear staining DAPI, panel 7) when recorded by immunofluorescence (Torriglia et al, 1995). The DNase II immunoreactivity is also restricted to the basal membrane.

These new results are of interest in studies on DNase II. The appearance of several DNase II bands recognised by the specific DNase II antibody suggests that DNase II may have HMW precursors, or may be linked with regulatory proteins.

\section{DNases with a single cation requirement}

The most important among these enzymes are probably the $\mathrm{Mg}^{2+}$-dependent enzymes, with a key role in DNA repair (Wallace, 1988). Basnak'yan et al (1989) have also described a $\mathrm{Mn}^{2+}$-dependent DNase (30 kDa) fractionated from rat liver chromatin, and Nikonova et al (1982) a $\mathrm{Ca}^{2+}$-dependent DNase in rat thymocytes. Recently, a calcium-dependent $15 \mathrm{kDa}$ endonuclease has been described in rat renal proximal tubules subjected to hypoxia/reoxygenation injury (Ueda et al, 1995). We have also observed in lens fibre cell nuclei, DNase activity dependent on one cation, either $\mathrm{Ca}^{2+}$ or $\mathrm{Mg}^{2+}$ (Muel et al, 1986). Lens fibre nuclei incubated $4 \mathrm{~h}$ in neutral Tris $\mathrm{HCl}$ medium, containing EDTA, EGTA and either $\mathrm{Ca}^{2+}$ or $\mathrm{Mg}^{2+}$, show a smear of DNA degradation by electrophoresis, indicating nuclear activation of one cation dependent DNases.

\section{Participation of these different nuclease activities in DNA cleavage}

The mechanism of DNA degradation and chromatin condensation is not well understood and the existence of several endonucleases has been postulated: DNase I (Peitsch et al, 1994). DNase II (Barry and Eastman 1992, 1993; Eastman, 1994), NUC 18 identified as cyclophilin (Gaido and Cidlowski, 1991; Montague et al, 1994) and the $97 \mathrm{kDa}$ endonuclease (Pandey et al, 1997).

In differentiating lens fibre cells where nuclei are physiologically programmed to disappear, we have observed all the types of DNases described in the literature. In an attempt to identify which endonucleases may be responsible for the various levels of endogenous DNA fragmentation, several studies were performed.

Using in situ nick translation reaction, we showed in chick lens fibre cells (E 18, Figure 8A) (Chaudun et al,

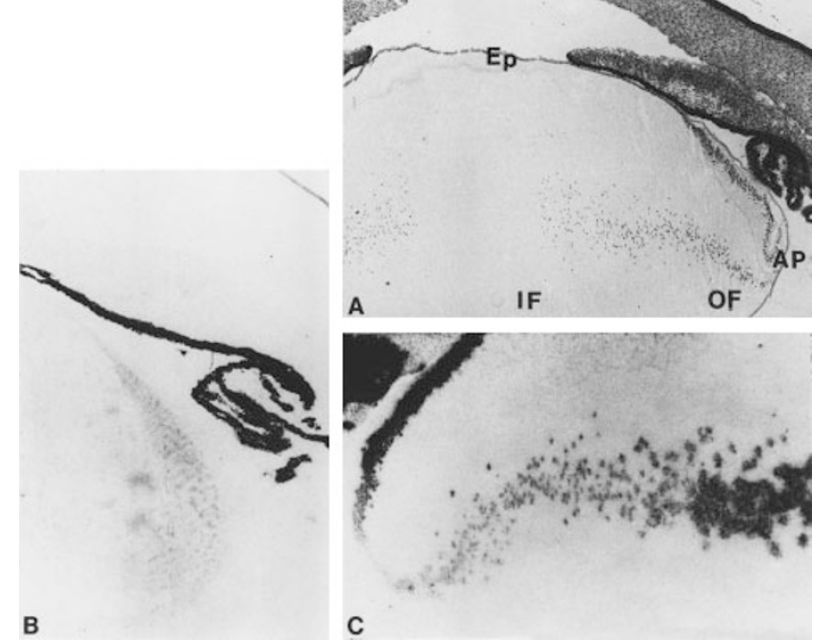

Figure 8 Histological staining and nick translation (NT) on sections of embryonic chick lens at E18. (A) $(\times 50)$ Embryonic chick lens section stained with hematoxylin and eosin at E18 showing the different cell types: epithelia (Ep), annular pad (AP), outer fibre cells (OF) and inner fibre cells (IF). (B and C) $(\times 95)$. Autoradiographs of sections fixed with methanol/acetic acid before NT in the absence (B) or in the presence (C) of DNase I. In (B), the cells show no single-strand breaks with $3^{\prime} \mathrm{OH}$ termini (Chaudun et al, 1994)

1994) that there was no accumulation of SSB with free $3^{\prime}$ $\mathrm{OH}$ ends on DNA (Figure 8B), as would be expected if a DNase of type I was responsible for DNA degradation (Figure 8C). In addition, Morgenbesser et al (1994) and Robinson et al (1995), recorded no DNA labelling by the TUNEL method, indicating that an addition to SSB, no DSB with free $3^{\prime} \mathrm{OH}$ were obtained suggesting a modest participation of DNase I-like nuclease. These results have led to the hypothesis that another DNase may be responsible for DNA cleavage.

When nuclei of epithelial cells are isolated (Figure 7A) in acidic medium (lanes $3-4$ ), or in the presence of $\mathrm{Ca}^{2+}, \mathrm{Mg}^{2+}$ (lanes 1-2), a mild DNA degradation is seen. This cleavage is inhibited neither by anti-DNase II (lane 4) nor by anti DNase I (lane 2). In contrast, when fibre nuclei are incubated in an acidic medium (Figure 7B, lanes 8-10), the medium devised for DNase II activity, there is strong DNA degradation (lane 8 ) that can be only blocked by the antibody directed against DNase II (Figure 7B, lanes 9-10).

Thus, these results strongly implicate DNase II in this process. We believe that DNases of type II could be responsible for the early events of DNA cleavage during this physiological process, since no nucleosomal ladder is seen. $\mathrm{A} \mathrm{Mg}^{2+}$-dependent endonuclease has been observed to cleave the high molecular weight DNA in other tissues e.g. liver and thymus (Cain et al, 1994; Cohen et al, 1994; Walker and Sikorska, 1994). This is not in contradiction with our results, since DNase II has been described to be active in the presence of $\mathrm{Mg}^{2+}$ (Bernardi and Sadron, 1964).

This type II nuclease from lens fibres is probably related to the deoxyribonuclease II described by Barry and Eastman (1993) in chinese hamster ovary cells. However, we have no reason to think that it may be a DNase 
producing nucleosomes such as the DNase I reported by Peitsch et al (1994) or the $97 \mathrm{kDa}$ nuclease from Pandey et al (1997). The DNase I is present in lens fibre nuclei but during in vitro nuclei incubation, this nuclease appears to have weak activity, since the $\mathrm{Ca}^{2+}, \mathrm{Mg}^{2+}$-dependent activity recorded (Figure 7B, lane 5) is not inhibited by a specific inhibitory antibody directed against DNase I (lanes 6-7; Torriglia et al, 1995).

In addition, we have shown the presence of different nuclease polypeptides active in $\mathrm{Ca}^{2+}, \mathrm{Mg}^{2+}$ medium. These results raise the possibility that there must exist another $\mathrm{Ca}^{2+}, \mathrm{Mg}^{2+}$-dependent DNase activity different from DNase I which may be implicated in the process of nucleosomal formation.

These results suggest that at least two different enzymes may be responsible for complete DNA degradation. This is in good agreement with the two activities described by Walker and Sikorska (1994) in the process of apoptosis, indicating a general pathway of concerted activation of DNases. We can then consider that among the two $\mathrm{Ca}^{2+}$, $\mathrm{Mg}^{2+}$-dependent fibre nuclease activities we have noted, one may play a role in nucleosomal formation. This DNase could be from the DNase I class, as identified by its $\mathrm{Ca}^{2+}$, $\mathrm{Mg}^{2+}$-dependence, but may not be related to DNase I. In addition, the $\mathrm{Ca}^{2+}, \mathrm{Mg}^{2+}$-dependent NUC 18 described by Cidlowski and coworkers (Gaido and Cidlowski, 1991; Montague et al, 1994) may be involved as well as a hypotonic-extracted $97 \mathrm{kDa}$ nuclease recorded by Pandey et al $(1994,1997)$. This apparent diversity of DNase molecules suggests different signalling pathways as Segal-Bendirdjan and Jacquemin-Sablon (1995) proposed.

\section{Modulators of nuclear degeneration while fibre cell cytoplasm remain all along the life-span}

We must remember that lens fibre cells lose their organelles, while the cells are still present in the organ, throughout their life-span. Thus some controls must exist in these differentiating cells that do not appear in cells committed to die.

Several factors can delay DNA cleavage. For example, $\mathrm{Zn}^{2+}$ is capable of blocking all DNases, including DNase II (Torriglia et al, 1997). Culture of E11 chick lenses in a medium lacking tryptophan delays DNA degradation (Counis et al, 1984), perhaps by inhibiting DNase synthesis or precursors of the DNA breakage cascade. Alternatively, acidic $\mathrm{pH}$ can accelerate the phenomenon of genomic cleavage (Barry and Eastman, 1992, 1993; Gottlieb et al, 1995). As fibre cells are acidophilic (Zwaan and Williams, 1968), this state could contribute to DNase II activation. It is important to note that even if DNase II has an optimal $\mathrm{pH}$ of activity in the acidic range, it is still able to degrade DNA at a neutral pH (Figure 9). Mitochondria may also induce DNA disappearance. In lens fibre cells, mitochondria are lost coincidentally with nuclei (Bassnett and Beebe, 1992) just before DNA degradation (Bassnett and Mataic, 1997) and could contribute, by liberating factors such as apoptotic inducing factor (AIF) or cytochrome $\mathrm{C}$ capable of inducing DNA breakdown (Kroemer et al, 1997). ng DNA/min

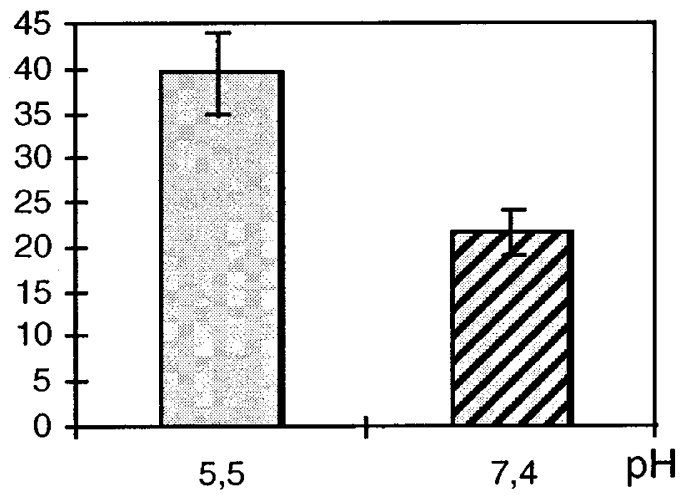

Figure 9 DNase II activity in acidic and neutral pH. $100 \mathrm{ng}$ of DNase II (Worthington) were incubated with $1 \mu \mathrm{g}$ of ${ }^{3} \mathrm{H}$-labelled DNA for $30 \mathrm{~min}$ at $37^{\circ} \mathrm{C}$, as described (Torriglia et al, 1995), in the presence of $10 \mathrm{mM}$ Tris, $10 \mathrm{mM}$ EDTA, pH 5.5 (grey column) or in the presence of $10 \mathrm{mM}$ Tris, $1 \mathrm{mM}$ EDTA, pH 7.4 (hatched column)

In the lens, there are various growth factors and/or oncogenes that can modulate the whole process of differentiation. Some of them may maintain cell cytoplasm survival while others may act to delete organelles. We have found fibroblast growth factors (FGF 1 and FGF 2) in embryonic chick retina at E11 and E18 (Mascarelli et al, 1987) and hypothesised, as have others, (Lovicu et al, 1995) that exogenous FGFs may induce lens differentiation. McAvoy and Chamberlain (1989) have shown that exogenous FGF induces lens epithelial cells, in explant culture, to proliferate, migrate and differentiate into fibre cells in a progressive concentration-dependent manner. We have observed during lens development an accumulation of FGF 1 in embryonic chick fibre cells, particularly in outer fibre cells (expressed as $\mathrm{ng} / 10^{8}$ cells; Table 2 ). The distribution of FGF 1 as well as the corresponding mRNA (Philippe et al, 1996) can thus be correlated with the pattern of differentiation in the lens, the greatest amount being concentrated in the nuclei of the outer fibres, a pattern not seen with FGF 2 (Cirillo et al, 1990). Lens fibre cells could be dependent on FGFs for their survival and differentiation (Chow et al, 1995) via either their receptor (Robinson et al, 1995; De longh et al, 1996) or an autocrine loop, since FGF 1 has no signal peptide (Renaud et al, 1996).

\section{Lens cell differentiation as a model for apoptotic events}

DNA degradation during fibre cell differentiation bears a number of similarities to apoptotic cells. Recently, Zelenka et al (1996) and Lang (1997) have suggested that lens cell terminal differentiation may be a special adaptation of the apoptotic process. Wride (1996) in another context, highlights the possible role of TNF $\alpha$ in loss of the lens cell nucleus and the role of apoptotic molecules e.g. ICE, bax and bcl2, suggesting a strong link between both processes. On the other hand Bassnett and Mataic (1997), using various 
Table 2 Amount of FGF1 in lens cells during differentiation

\begin{tabular}{|c|c|c|c|c|}
\hline & $\begin{array}{c}\text { Epithelial FGF } 1 \\
\text { ng/ml protein }\end{array}$ & $\begin{array}{c}\text { Epithelial FGF } 1 \\
\mathrm{ng} / \mathrm{ml} / 10^{8} \text { cells }\end{array}$ & $\begin{array}{c}\text { Fibre FGF } 1 \\
\text { ng/mg protein }\end{array}$ & $\begin{array}{c}\text { Fibre FGF } 1 \\
\mathrm{ng} / \mathrm{ml} / 10^{8} \text { cells }\end{array}$ \\
\hline E 11 total tissue & $2.4 \pm 0.4$ & $5.1 \pm 0.6$ & $0.44 \pm 0.03$ & $11.9 \pm 0.9$ \\
\hline $\begin{array}{l}\text { E } 18 \text { total tissue } \\
\text { outer fiber } \\
\text { inner fiber }\end{array}$ & $202.6 \pm 62.4$ & $31.1 \pm 5$ & $\begin{array}{c}65.6 \pm 5.7 \\
101.9 \\
24.6\end{array}$ & $201.0 \pm 27.2$ \\
\hline $\begin{array}{l}\mathrm{PH} 1 \mathrm{~d} \text { total tissue } \\
\text { outer fiber } \\
\text { inner fiber }\end{array}$ & $208.0 \pm 55.1$ & & $\begin{array}{c}58.5 \pm 0.7 \\
71.6 \\
29.4\end{array}$ & \\
\hline $\begin{array}{l}\mathrm{PH} 3 \mathrm{~m} \text { total tissue } \\
\text { outer } \mathrm{F} \\
\text { inner } \mathrm{F}\end{array}$ & $89.6 \pm 28.7$ & & $\begin{array}{c}27.2 \pm 10.9 \\
24.1 \\
5.5\end{array}$ & \\
\hline
\end{tabular}

E: embryonic stage. $\mathrm{PH}$ : post hatched stage. d: day, m: month

morphological and chronological criteria believe that the process of lens cell differentiation is distinct from apoptosis. One of their major arguments is that in lens fibre cells, the organelles disappear 2-3 days before DNA fragmentation while in apoptotic cells, including lens epithelial cells ( $\mathrm{Li}$ et al, 1995), the organelles are still present after DNA has been degraded. In addition, they point out that there is no membrane blebbing or formation of apoptotic bodies. Nevertheless, evidence of: the accumulation of G1 cyclins without initiating DNA synthesis; the expression of $p 34^{\text {cdc2 }}$ in fibre cells (Zelenka, 1996); the induction of apoptosis in lenses from $\mathrm{p} 53^{-1-}$ mice in which the $\mathrm{Rb}$ function is inactivating by the HPV E7 oncoprotein at the time that nuclear degeneration begins (Pan and Griep, 1995), and the degradation pattern of DNA in fibre cells, support the idea of a biochemical link between apoptosis and loss of the fibre cell nucleus. This idea is also supported by recent work. Transgenic mice were generated that overexpress bcl-2 in a lens specific fashion. Overexpression of bcl-2 was sufficient to interfere with normal lens cell differentiation. A cell disorganisation is seen, as well as inhibition of loss of the lens cell nucleus (Fromm and Overbeek, 1997).

Recent evidence has demonstrated that mitochondria are required for apoptosis, probably through release of cytochrome C (Kroemer et al, 1997; Yang et al, 1997; Kluck et al, 1997). The resulting activation of caspases degrades many proteins in both the cytoplasm and the nucleus. If caspases are activated in the lens, it would appear that terminally differentiated cells would have no chance of long term survival. Hence, by deleting the mitochondria before the nuclei instead of afterwards, the cells are able to survive. This might be the difference between differentiation and apoptosis in the lens. This would also suggest that in the lens a different pathway is required to activate nucleases because the cells now lack mitochondria.

\section{Conclusion}

In conclusion, the lens is an interesting model for studying patterns of nuclear degeneration and DNA cleavage. Its fibre cells contain or receive the information which leads to their nuclear disappearance, while the cytoplasm is conserved throughout the life-span. It is, thus, a differentiating system which is interesting to compare with a true apoptotic one. In 1977, we had shown that DNA was broken into multi-step fractions, i.e. high molecular and oligonucleosomal DNA fragments. The chromatin was condensed in the last steps before nuclear disappearance, mimicking apoptotic nuclei. Lens fibre nuclei, as all nuclei, contain several kinds of DNases and the understanding of their presence and function is highly complex. The activity of these nucleases must be partially blocked, implicating subtle regulation, probably via proteases, but no studies have been done on these molecules.

Among several $\mathrm{Ca}^{2+}, \mathrm{Mg}^{2+}$-dependent DNases including DNase I, mono-cationic $\left(\mathrm{Ca}^{2+}\right.$ or $\left.\mathrm{Mg}^{2+}\right)$ nucleases and noncationic DNase (DNase II), we have been able to strongly implicate DNase II in this process. DNase II regulation is poorly understood. It is supposedly a lysosomal enzyme, while in our model, it has been found located in the nuclei of these differentiating cells. It is active in fibre nuclei when incubated in acidic buffer, a medium devised only for noncationic DNase. Under these conditions, only the antiDNase II antibody can inhibit the acidic DNA degradation. If DNase II seems very important, we cannot exclude a complementary role for DNase I, located in all fibre nuclei. However, it is probably a minor one as the DNA degradation observed in a $\mathrm{Ca}^{2+}, \mathrm{Mg}^{2+}$ buffer, specific for cationic DNases cannot be inhibited by anti-DNase I. Thus, we presume that another DNase of the $\mathrm{Ca}^{2+}, \mathrm{Mg}^{2+}$ class may be an additional factor in this complex process. This regulation may also involve multiple additional factors including post-translational modifications of the DNases, $\mathrm{pH}$, mitochondrial release factors, oncogenes and/or trophic factors including FGF 1.

\section{Acknowledgements}

Polyclonal antibody directed against HMG14 was obtained from R Westermann, Department of Anatomy and Cell Biology, PhilippsUniversity, Marburg, Germany. Histone $\mathrm{H} 1$ antibody was from S. Muller, Department of Immunology, IBMC, Strasbourg, France and characterised by Stemmer et al (1994). C. Arruti was supported by an ECOS program between France and Uruguay, Action 95B01 and A. Torriglia by a fellowship from AFRP (Association Française Retinitis Pigmentosa). We are grateful to Prof McDewitt for assistance with preparation of this manuscript in English. 


\section{References}

Appleby DW and Modak SP (1977) DNA degradation in terminally differentiating lens fiber cells from chick embryos. Proc. Natl. Acad. Sci. USA 74: 5579-5583

Arends MJ and Wyllie AH (1991) Apoptosis: mechanisms and roles in pathology. International Rev. Exp. Pathology 32: 223-254

Arends MJ, Morris RG and Wyllie AH (1990) Apoptosis. The role of the endonuclease. American J. Pathol. 136: 593-608

Arruti C, Chaudun E, DeMaria A, Courtois Y and Counis MF (1995) Characterisation of eye-lens DNases: long term persistence of activity in post apoptotic lens fibre cells. Cell Death Differ. 2: 47-56

Barry MA and Eastman A (1993) Identification of deoxyribonuclease II as an endonuclease involved in apoptosis. Archives Biochem. Biophys. 300:400-450

Barry MA and Eastman A (1992) Endonuclease activation during apoptosis: the role of cytosolic $\mathrm{Ca}^{2+}$ and pH. Biochem. Biophys. Res. Comm. 186: 782-789

Basnak'yan AG, Bubnov NV and Votrin II (1989) DNases of cell nuclei: multiplicity and heterogeneity. Biochemistry USSR (Biokhimiya) 54: 207-216

Bassnett S and Beebe DC (1992) Coincident loss of mitochondria and nuclei during lens fiber cell differentiation. Develop. Dynamics 194: 85-93

Bassnett S (1995) The fate of the golgi apparatus and the endoplasmic reticulum during lens fiber cell differentiation. Invest. Ophthal. Visual Sci. 36: 1793-1803

Bassnett $S$ and Mataic D (1997) Chromatin degradation in differentiating fiber cells of the eye lens. J. Cell Biol. 137: 37-49

Bernardi G (1971) Spleen acid deoxyribonuclease. in The Enzymes 4: 271-287 Boyer PD ed.

Bernardi G and Sadron C (1964) Studies on acid deoxyribonuclease. I Kinetics of the initial degradation of deoxyribonucleic acid by acid deoxyribonuclease. Biochemistry 3: 1411-1418

Bradley RH, Ireland M and Maisel H (1979) The cytoskeleton of chick lens cells. Exp. Eye Res. 28: 441-453

Cain K, Inayat-Hussain SH, Wolfe JT and Cohen GM (1994) DNA fragmentation into $200-250$ and/or 30 - 50 kilobase pair fragments in rat liver nuclei is stimulated by $\mathrm{Mg}^{2+}$ alone and $\mathrm{Ca}^{2+} / \mathrm{Mg}^{2+}$ but not by $\mathrm{Ca}^{2+}$ alone. FEBS Lett. 349: 385-391

Chaudun E, Arruti C, Courtois Y, Ferrag F, Jeanny JC, Patel BN, Skidmore C, Torriglia A and Counis MF (1994) DNA strand breakage during physiological apoptosis of the embryonic chick lens: free $3^{\prime} \mathrm{OH}$ end single strand breaks do not accumulate even in the presence of a cation-independent deoxyribonuclease. J. Cell Physiol. 158: $354-364$

Chow RL, Diez Roux G, Roghani M, Palmer MA, Rifkin DB, Moscatelli DA and Lang RA (1995) FGF suppresses apoptosis and induces differentiation of fibre cells in the mouse lens. Development 121: 4383-4393

Cirillo A, Arruti C, Courtois Y and Jeanny J-C (1990) Localization of basic fibroblast growth factor binding sites in the chick embryonic neural retina. Differentiation 45: $161-167$

Cohen GM, Sun X-M, Fearnhead H, MacFarlane M, Brown DG, Snowden RT and Dinsdale D (1994) Formation of large molecular weight fragments of DNA is a key committed step of apoptosis in thymocytes. J. Immunol. 153: 507-516

Counis MF, Chaudun E and Courtois Y (1977) DNA synthesis and repair in terminally differentiating embryonic lens cells. Dev. Biol. 57: 47-55

Counis MF, Chaudun E, Allinquant B, Muel AS, Sanwal M, Skidmore C and Courtois Y (1989a) The lens: a model for chromatin degradation studies in terminally differentiating cells. Int. J. Biochem. 21: 235-242

Counis MF, Chaudun E, Carreau JP and Courtois Y. (1984) Changes in the DNA breakage and crystallin synthesis of embryonic chicken lenses cultured in a tryptophan-deficient medium. Exp. Eye Res. 38: 1-6

Counis MF, Chaudun E, Courtois Y and Allinquant B (1989b) Lens fiber differentiation correlated with activation of two different DNAases in lens embryonic cells. Cell Diff. Dev. 27: 137-146

Counis MF, Chaudun E, Muel AS, Courtois Y and Modak SP (1986) Endodeoxyribonuclease activity in lens cells during chick embryonic development. Modern trends in aging research 147: 285-291 Colloque INSERM-Eurage, Libbey, J. eds

Counis MF, David JC, Chaudun E and Carre D (1981) DNA polymerase, DNA ligase and thymidine kinase activity in chicken lens, related to DNA X-ray lesion repair. Differentiation 20: $188-195$

Cvekl A and Piatigorsky J (1996) Lens development and crystallin gene expression: many roles for Pax-6. BioEssays 18: 621-630
Delongh RU, Lovicu FJ, Hanneken A, Baird A and McAvoy JW (1996)FGF receptor-1 $(f / g)$ expression is correlated with fibre differentiation during rat lens morphogenesis and growth. Develop. Dynamics 206: 412-426

Eastman A. (1994) Deoxyribonuclease II in apoptosis and the significance of intracellular acidification. Cell Death Differ. 1: 7-9

Fromm L and Overbeek PA (1997) Inhibition of cell death by lens specific overexpression of bcl-2 in transgenic mice. Develop. Genetics 20: 276-287

Gaido ML and Cidlowski JA (1991) Identification, Purification and characterization of a calcium-dependent endonuclease (NUC18) from apoptotic rat thymocytes. NUC18 is not histone H2B. J. Biol. Chem. 266: 18580-18585

Gopalakrishnan S and Takamoto L (1992) Binding of actin to lens alpha crystallins. Current Eye Res. 11: 929-933.

Gottlieb R, Giesing HA, Engler RL and Babior BM (1995) The acid deoxyribonuclease of neutrophils: a possible participant in apoptosis-associated genome destruction. Blood 86: 2414-2418

Hewish DR and Burgoyne LA (1973) Chromatin sub-structure. The digestion of chromatin DNA at regularly spaced sites by a nuclear deoxyribonuclease. Biochem. Biophys. Res. Comm. 52: 504-510

Kluck RM, Bossy-Wetzel E, Green DR and Newmeyer D (1997) The release of cytochrome $c$ from mitochondria: a primary site for $\mathrm{Bcl}-2$ regulation of apoptosis. Science 275: $1132-1136$

Kroemer G, Zamzami N and Susin SA (1997) Mitochondrial control of apoptosis. Immunol. Today 18: 44-51

Kuwabara T and Imaizumi M (1974) Denucleation process of the lens. Invest. Ophthalmol. 13: 973-981

Lack SA (1981) Deoxyribonuclease I in mammalian tissues. Specificity of inhibition by actin. J. Biol. Chem. 256: 2644-2648

Lang RA (1997) Apoptosis in mammalian eye development: lens morphogenesis, vascular regression and immune privilege. Cell Death Differ. 4: 12-20

Li W-C, Kuszak JR, Wang G-M, Wu Z-Q and Spector A (1995) Calcimycin-induced lens epithelial cell apoptosis contributes to cataract formation. Exp. Eye Res. 61: $91-98$

Liao T-H, Liao W-C, Chang H-C and Lu K-S (1989) Deoxyribonuclease Il purified from the isolated lysosomes of porcine spleen and from porcine liver homogenates. Comparison with deoxyribonuclease II purified from porcine spleen homogenates. Biochim. Biophys. Acta 1007: 15-22

Lovell-Badge R (1995) Living with bad architecture. The HMG family proteins. Nature 376: $725-726$

Lovicu FJ, Chamberlain CG and McAvoy JW (1995) Differential effects of aqueous and vitreous on fiber differentiation and extracellular matrix accumulation in lens epithelial explants. Invest. Ophtal. Visual Sc. 36: 1459-1469

Mannherz HG (1992) Crystallization of actin in complex with actin-binding proteins. J. Biol. Chem. 267: 11661-11664

Mascarelli F, Raulais D, Counis MF and Courtois Y (1987) Characterization of acidic and basic fibroblast growth factors in brain, retina and vitreous chick embryo. Biochem. Byophys. Res. Comm. 146: 478-486

McAvoy JW and Chamberlain CG (1989) Fibroblast growth factor (FGF) induces different responses in lens epithelial cells depending on its concentration. Development 107: 221-228

Mezzina M, Nocentini S, Nardelli J, Ranault G, Moustacchi E and Sarasin A (1989) Enhanced deoxyribonuclease activity in human transformed cells and in Bloom's syndrome cells. Molecular Carcinogenesis 2: 179-183

Modak SP and Perdue SW (1970) Terminal lens cell differentiation. I Histological and microspectrophotometric analysis of nuclear degeneration. Exp. Cell Res. 59: $43-56$

Modak SP, Von Borstel RC and Bollum FJ (1969) Terminal lens cell differentiation. II Template activity of DNA during nuclear degeneration. Exp. Cell Res. 56: 105113

Montague JW, Gaido ML, Frye C and Cidlowski JA (1994) A calcium-dependent nuclease from apoptotic rat tymocytes is homologous with cyclophilin. Recombinant cyclophilins A, B and C have nuclease activity. J. Biol. Chem. 269: $18877-18880$

Moore S (1981) Pancreatic DNase. In the Enzymes 14: 281 -296, Boyer, PD. ed.

Morgenbesser SD, Williams BO, Jacks T and DePinho RA (1994) p53-dependent apoptosis produced by $R b$-deficiency in the developing mouse lens. Nature 371 : $72-74$ 
Muel AS, Chaudun E, Courtois Y, Modak SP and Counis MF (1986) Nuclear endogenous $\mathrm{Ca}^{2+}$-dependent endodeoxyribonuclease in differentiating chick embryonic lens fibers. J. Cell Physiol. 127: 167-174

Muel AS, Laurent M, Chaudun E, Alterio J, Clayton R, Courtois Y and Counis MF (1989) Increased sensitivity of various genes to endogenous DNase activity in terminal differentiating chick lens fibers. Mutation Res. 219: 157-164

Nikonova LV, Nelipovich PA and Umansky SR (1982) The involvement of nuclear nucleases in rat thymocytes DNA degradation after $\gamma$-irradiation. Biochim. Biophys. Acta. 699: 281-289

Pan H and Griep AE (1995) Temporally distinct patterns of p53-dependent and p53independent apoptosis during mouse lens development. Genes Dev. 9:2157 2169

PandeyS, Walker PR and Sikorska M (1994) Separate pools of endonuclease activity are responsible for internucleosomal and high molecular mass DNA fragmentation during apoptosis. Biochem. Cell Biol. 72: 625-629

Pandey S, Walker PR and Sikorska M (1997) Identification of a novel $97 \mathrm{kDa}$ endonuclease capable of internucleosomal DNA cleavage. Biochemistry 36 : $711-720$

Peitsch MC, Polzar B, Tschopp J and Mannherz HG (1994) About the involvement of deoxyribonuclease I in apoptosis. Cell Death Differ. 1: 1-6

Philippe JM, Renaud F, Courtois Y and Laurent M (1996) Cloning of multiple chicken FGF1 mRNAs and their differential expression during development of whole embryo and of the lens. DNA and Cell Biol. 15: 703-715

Piatigorsky J (1981) Lens differentiation in vertebrates: A review of cellular and molecular features. Differentiation 19: 134-153

Polzar B and Mannherz HG (1991) Nucleotide sequence of a full length cDNA clone encoding the deoxyribonuclease I from the rat parotid gland. Nucleic. Acids Res. 18: 7151

RenaudF, Desset S, Oliver L, Gimenez-Gallego G, Van Obberghen E, Courtois Y and Laurent M (1996) The neurotrophic activity of fibroblast growth factor I (FGF 1) depends on endogenous FGF 1 expression and is independent of the mitogenactivated protein kinase cascade pathway. J. Biol. Chem. 271: 2801-2811

Robinson ML, MacMillan-Crow LA, Thompson JA and Overbeek PA (1995) Expression of a truncated FGF receptor results in defective lens development in transgenic mice. Development 121: 3959-3967

Roche J, Chaudun E, Courtois Y, Ferrag F, Jeanny JC, Muller S, Sanwal M and Counis MF (1992) Histone deposition and metabolism in embryonic chick lenses during differentiation. Exp. Eye Res. 55: 183-187

Sandilands A, Prescott AR, Carter JM, Hutcheson AM, Quinlan RA, Richards J and FitzGerald PG (1995) Vimentin and CP 49/ filensin form distinct networks in the lens which are independently modulated during lens fibre cell differentiation. J. Cell Sci. 108: 1397-1406

Sanwal M, Muel AS, Chaudun E, Courtois Y and Counis MF (1986) Chromatin condensation and terminal differentiation process in embryonic chicken lens in vivo and in vitro. Exp. Cell Res. 167: 429-439

Segal-Bendirdjian E and Jacquemin-Sablon A (1995) Cisplatin resistance in a murine leukemia cell line is associated with a defective apoptotic process. Exp. Cell Res. 218: 201-212

Shak S, Capon D, Hellmiss R, Marsters SA and BakerCL (1990) Recombinanthuman DNase I reduces the viscocity of cystic fibrosis sputum. Proc. Natl. Acad. Sci. USA 87: $9188-9192$

SlorH and Lev T (1971) Acid deoxyribonuclease activity in purified calf thymus nuclei. Biochem. J. 123: 993-995
Stemmer C, Briand J-P and Muller S (1994) Mapping of linear epitopes of human histone $\mathrm{H} 1$ recognized by rabbit anti- $\mathrm{H} 1 / \mathrm{H} 5$ antisera and antibodies from autoimmune patients. Molecular Imminol. 31: 1037-1046

Torriglia A, Chaudun E, Chany-Fournier F, Jeanny JC, Courtois $Y$ and Counis MF (1995) Involvement of DNase II in nuclear degeneration during lens cell differentiation. J. Biol. Chem. 270: 28579-28585

Torriglia A, Chaudun E, Courtois $Y$ and Counis MF (1997) On the use of $\mathrm{Zn}^{2+}$ to discriminate endonucleases activated during apoptosis. Biochimie 79: 435438.

Trevithick JR, Chaudun E, Muel AS, Courtois Y and Counis MF (1987) Effects of Xirradiation and vitamin $C$ on DNA degradation and endogenous DNase in embryonic chick lens cells. Curr. Eye Res. 6: 1275-1281

Trieschmann L, Postnikov YV, Rickers A and Bustin M (1995) Modular structure of chromosomal proteins HMG-14 and HMG-17: definition of a transcriptional enhancement domain distinct from the nucleosomal binding domain. Mol. Cell. Biol. 15: 6663-6669

Ucker DS, Obermiller PS, Eckhart W, Apgar JR, Berger NA and Meyers J (1992) Genome digestion is a dispensable consequence of physiological cell death mediated by cytotoxic T lymphocytes. Mol. Cell. Biol. 12: 3060-3069

Ueda N, Walker PD, Hsu S-M and Shah SV (1995) Activation of a $15-\mathrm{kDa}$ endonuclease in hypoxia/reoxygenation injury without morphologic features of apoptosis. Proc. Natl. Acad. Sci. USA 92: 7202-7206

Vrensen GFJM, Graw J and De Wolf A (1991) Nuclear breakdown during terminal differentiation of primary lens fibres in mice: a transmission electron microscopic study. Exp. Eye Res. 52: 647-659

Walker PR and Sikorska M (1994) Endonuclease activities, chromatin structure and DNA degradation in apoptosis. Biochem. Cell. Biol. 72: 615-623

Wallace SS (1988) AP endonucleases and DNA glycosylases that recognize oxidative DNA damage. Environ. mol mutagen. 12: 431-477

Worrall AF and Connolly BA (1990) The chemical synthesis of a gene coding for bovine pancreatic DNase I and its cloning expression in Escherichia coli. J. Biol. Chem. 265: 21889-21895

Wride MA (1996) Cellular and molecular features of lens differentiation: a review of recent advances. Differentiation 61: 77-93

Wyllie AH (1980) Glucocorticoid-induced thymocyte apoptosis is associated with endogenous endonuclease activation. Nature 284: $555-556$

Wyllie AH, Kerr JF and Currie AR (1980) Cell death: the significance of apoptosis. Int. Rev. Cytol. 68: 251-306

Yamamoto A, Araki T and Counis MF (1990) Decrease of DNA per cell during development of the lens in chickens. Histochemistry 94: 293-296

Yang J, Liu X, Bhalla K, Kim CN, Ibrado AM, Cai J, Peng T-I, Jones DP and Wang W (1997) Prevention of apoptosis by Bcl-2: release of cytochrome c from mitochondria blocked. Science 275: 1129-1132

Yasuda T, Nadano D, Awazu S and Kishi K (1992) Human urine deoxyribonuclease-II (DNase II) isoenzymes: a novel immunoaffinity purification, biochemical multiplicity, genetic heterogeneity and broad distribution among tissues and body fluids. Biochim. Biophys. Acta. 1119: 185-193

Zelenka PS, Gao C-Y, Rampalli A, Arora J, Chauthaiwale V and He H-Y (1996) Cell cycle regulation in the lens: proliferation, quiescence, apoptosis and differentiation. Prog. Ret. Eye Res. 16: 303-322

Zwaan J and Williams RM (1968) Morphogenesis of the eye lens in a mouse strain with hereditary cataracts. J. Exp. Zool. 169: 407-422 